\title{
局所投与抗生剂の鼻, 副鼻腔粘膜組織内移行に関する検討
}

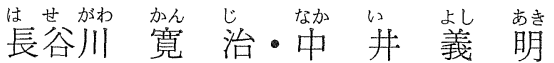

緒

言

鼻炎, 副鼻腔炎に対する治療の内, 保存的治療として, 抗生剤, 醭素製剤, 抗ヒス夕ミン剂, 副 腎皮質ホルモンなどが使用されている，特に抗生剤に関しては次々と新らしい製剤が開発される が, 慢性疾患に対しては, その効果に疑問の点が多い. その問題点の一つとして細菌の最小発育阻 止濃度との関係において, 病巣組織内の抗生物質濃度の問題点があると考えられる. 従来, 鼻炎及 び副鼻腔炎に対する効果は，投与された抗生剤が鼻腔およで副鼻腔の他覚的所見ならびに自覚的所 見に, ぞの様な影響を与えるかによって判定が行なわれてきた ${ }^{122)}$. あるいはまた病巣組織内の抗生 物質濃度の点からも検討がなされ, 多くの報告 ${ }^{32}$-5)がるられるが, いずれも充分な知見が得られて いるとはいい難い。つまり慢性鼻炎, 慢性副鼻腔炎の場合, 全身投与では, 粘膜内移行度は極めて 不良で, 従って粘膜内濃度も低く, 有効濃度を確保し難いといえる ${ }^{6)}$ ８). 乙の点局所投与が望まし いと考えられる. 今回, 私共は CEZ (Cefazolin) のネブライザー投与と上顎洞注入による粘膜へ の吸収ならびにその病理組織学的所見との関係を検討した.

\section{方}

鼻苜切除術，下甲介切除術，および慢性副鼻 腔炎根治術を施行した際の病巣剔出標本を試料 とした．鼻苗切除術，下甲介切除術の場合は， 術前約30分前に鼻腔内を生食水で洗浄後, 蒸留 水 $2 \mathrm{cc}$ 亿溶解した Cefazolin（以下 $\mathrm{CEZ}$ と略 す） $0.5 \mathrm{~g}$ のネブライザーを行なった，副鼻腔 炎根治術の場合は，術前約 3 時間前に上顎洞穿 刺を行ない, 生食水による洞洗浄後, 蒸留水 $3 \mathrm{cc}$ に溶解した CEZ $1 \mathrm{~g}$ の洞内注入を行なっ た. 剔出した鼻腔および副鼻腔粘膜は, 分泌物 ，血液その他を $100 \mathrm{cc}$ の生理的食塩水にて約 5 分間洗浄し，ガーゼで允分清拭し，可及的速や かに判定した。なお副鼻腔炎根治術の場合は, 上顎洞下部および後部の粘膜を試料とした。一 一 方手術時の麻酔は，鼻苜切除では $4 \%$ キシロカ
法

イン $2 \operatorname{cc} の$ 表面麻酔，下甲介切除の場合 $1 \%$ キ シロカイン約 $1 \mathrm{cc} の$ 粘膜内麻酔, 上顎洞粘膜採 取の場合は局所への薬物使用は避けた。

測定方法：薬剤組織内濃度測定は, Disc 法 で生物学的方法によった. 試験菌は, Bacillus subtilis ATCG-6633 を用いた. 標準曲線作製 時の希釈液は, phosphate buffer を使用し, 培地は普通寒天培地（ポリペプトン $5 \mathrm{~g}$, 肉工 キス $3 \mathrm{~g}$ ，クエン酸ナトリウム $10 \mathrm{~g}$ ，寒天末 $10 \mathrm{~g}$ ，注水を加えて $1000 \mathrm{ml}$ とする）培養時間は 20 時間，培養温度は $37^{\circ} \mathrm{C}$ を用いた。 組織の処 理は, 組織重量と等量の $1 / 15 \mathrm{M}$ phosphate buffer（pH 7.0）を加え，ポリトロンホモゲル イザーで処理後, 3000 r.p.m 10 分遠心分離し, その上清液について Bioassay を行なった。

Concentration of a Locally Administered Antibiotic into the Nasal and Paranasal Sinus Mucosa.

Kanji Hasegawa and Yoshiaki Nakai.

*大阪市立大学医学部耳鼻咽喉科学教室（主任：山本 蕃教授） 
成

検体は鼻咠20例, 肥厚性鼻炎16例, 慢性副鼻 腔炎15例で，GEZ の組織内濃度は図1亿示さ れている如くである。採取試料による差がかな り多いが，鼻茸組織内濃度は平均 $14 \mathrm{mcg} / \mathrm{g}$, 下甲介粘膜では平均 $27 \mathrm{mcg} / \mathrm{g}$, 上顎洞粘膜で は平均 $69 \mathrm{mcg} / \mathrm{g}$ であった. 上顎洞粘膜組織内 濃度が最大であるが，乙れは薬剤の投与量が大 である事（2 倍)，投与方法が異なる事が大き な因子であると考光られる。同一疾患において も，その組織内濃度に大きな差がみられるの で，次に上記三種類各例について病理組織的検 索を行なった．各研究者によって病理組織的分 類法がやや異なり，また同一症例についてで も，各型が混在している例も多くみられたが， おおよその傾向として以下の型のように大きく

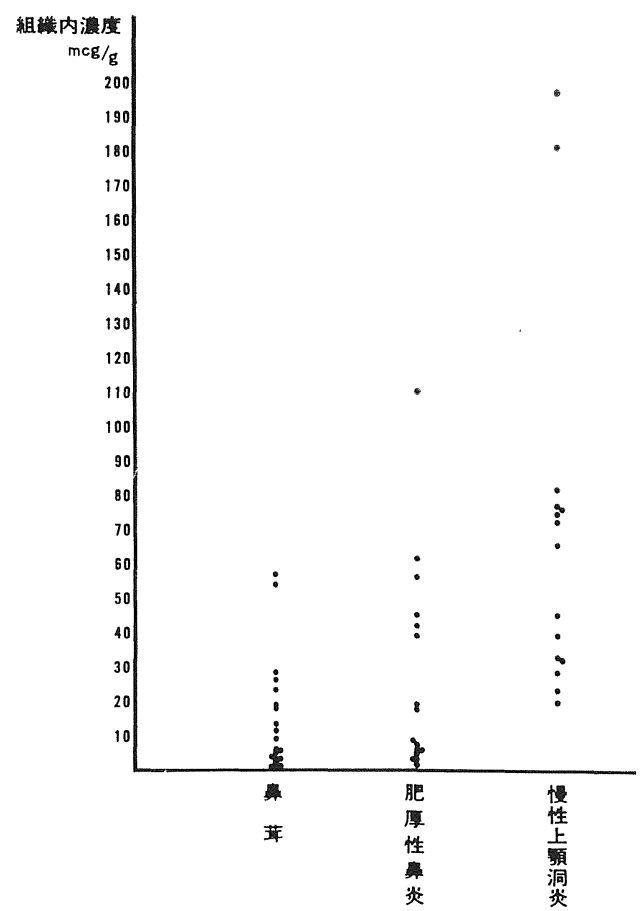

図 $1 \mathrm{GEZ}$ 投守後の鼻直, 肥厚性舅炎, 慢性上 顎洞炎各粘膜組織内濃度

\section{續}

分類を試みた。鼻茸では，細胞浸潤型，浮腫 型, 線維型, これらの混在した混合型（网 2 , 図 3 ），下甲介粘膜では実質の増大があって細 胞数増加が少ない肥大型, 細胞数増加が主であ る肥厚型，およびこの両者の混合型（図 4 , 図 5 ), 慢性副鼻腔炎粘膜では, 浮腫型, 因牙型, 線維型, 炎症像軽度の軽症型（図 6,困 7 ) 亿分 類した. 各症例についての組織内濃度と病理組 織との関係は，表 $1 ， 2 ， 3$ 亿示している.鼻 茸では，浮腫型に薬剤の浸入量が他の型に比べ 著しく少なく，下甲介粘膜では，肥大型が肥曆 型に比べ楽剤の浸入の程度が大であった。慢性 副鼻腔炎粘膜では，細胞浸潤の大である肉牙型 が，薬剤浸入量は少なく，軽症型は大であっ た.

表 1 GEZ (0.5g) ネブライザー投与後の鼻茸組 織内濃度およびその病理組織型.

鼻咠

\begin{tabular}{c|c|c}
\hline \hline 症 例 & 組織内濃度 $(\mathrm{mcg} / \mathrm{g})$ & 病理組織 \\
\hline 1 & 19.5 & 浸 潤 型 \\
2 & 5.22 & 浮 腫 型 \\
3 & 1.44 & 浮 腫 型 \\
4 & 1.32 & 浮 腫 型 \\
5 & 5.1 & 線 維 型 \\
6 & 6.2 & 浮 腫 型 \\
7 & 13.8 & 混 合 型 \\
8 & 57.1 & 浸 潤 型 \\
9 & 0.95 & 浮 腫 型 \\
10 & 54.6 & 浸 潤 型 \\
11 & 9.7 & 線 維 型 \\
12 & 3.7 & 浮 腫 型 \\
13 & 4.3 & 浮 腫 型 \\
14 & 28.8 & 浸 潤 型 \\
15 & 11.9 & 混 合 型 \\
16 & 23.6 & 浸 潤 型 \\
17 & 2.4 & 浮 腫 型 \\
18 & 3.1 & 浮 腫 型 \\
19 & 26.3 & 浸 潤 型 \\
20 & 18.6 & 浸 潤 型 \\
& & 型
\end{tabular}


表 2 GEZ (0.5g) ネブライザー投与後の下鼻甲 介粘膜内濃度およびその病理組織型。 肥厚性鼻炎

\begin{tabular}{c|c|c}
\hline \hline 症 例 & 組織内濃度 $(\mathrm{mcg} / \mathrm{g})$ & 病理組織 \\
\hline 1 & 110.0 & 肥 大 型 \\
2 & 61.5 & 肥 大 型 \\
3 & 3.3 & 肥 厚 型 \\
4 & 18.0 & 肥 大 型 \\
5 & 6.4 & 肥 厚 型 \\
6 & 2.8 & 混 合 型 \\
7 & 7.9 & 肥 厚 型 \\
8 & 45.1 & 肥 大 型 \\
9 & 56.3 & 肥 大 型 \\
10 & 42.4 & 肥 大 型 \\
11 & 6.6 & 肥 厚 型 \\
12 & 19.2 & 肥 大 型 \\
13 & 5.3 & 肥 厚 型 \\
14 & 3.4 & 肥 厚 型 \\
15 & 8.6 & 混 合 型 \\
16 & 39.6 & 肥 大 型 \\
& &
\end{tabular}

考

鼻炎，副鼻腔炎に対する保存的療法として， ネブライザーは 1949年西端9)により我国にはじ めて紹介されて以来，耳鼻咽喉科で最も手軽に 使える治療法の一つとして用いられている ${ }^{10)}$. このネブライザーに使用する薬剤として，抗生 剤，酵素製剂，抗ヒス夕ミン剤，副腎皮質ホル モンなに゙，备種の薬剤が使用されている．との ネブライザーの 効果に関しての 報告 ${ }^{12)}$ ととも に, 鼻, 副鼻腔粘膜病的組織内の抗生物質濃度 に関しては，古くは坂倉の報告が，最近になっ ては，守安 $~^{3)}$ ，藤谷ら ${ }^{4)}$ ，三吉 $5^{5)}$ の報告がみ られる。守安ら ${ }^{3)}$ は, AB-PG (aminobenzyl penicillin), MGI-PG (methylchlorophenyl isoxazolyl penicillin, AKM (aminodeoxy kanamycin）の全身投与では，AB-PG 125〜 $250 \mathrm{mg}$ 投与にて 約 $0 \sim 1 \mathrm{mcg} / \mathrm{g}$, MGI-PG 125 ～250mg 投与にて約 $0 \sim 2 \mathrm{mcg} / \mathrm{g}, \mathrm{AKM} 200$ $\mathrm{mg}$ 投与にて $0 \sim 30 \mathrm{mcg} / \mathrm{g}$ でいずれも今回の 私共の $\mathrm{CEZ}$ 測定值に比べ低い值を示してい る。ネブライザ一による局所投尗では， $\mathrm{AB}=\mathrm{PC}$
表 3 GEZ（1.0g）上䫟洞内注入後の粘㸟内濃度 およびその病理組織型. 慢性上顎洞炎

\begin{tabular}{c|c|c}
\hline \hline 症 例 & 組織内濃度 $(\mathrm{meg} / \mathrm{g})$ & 病理組織 \\
\hline 1 & 45.0 & 肉 芽 型 \\
2 & 39.0 & 肉 芽 型 \\
3 & 81.9 & 軽 症 型 \\
4 & 33.0 & 肉 芽 型 \\
5 & 76.5 & 軽 症 型 \\
6 & 180.0 & 軽 症 型 \\
7 & 196.0 & 軽 症 型 \\
8 & 20.1 & 肉 牙 型 \\
9 & 76.0 & 軽 症 型 \\
10 & 23.5 & 肉 牙 型 \\
11 & 32.4 & 浮 腫 型 \\
12 & 72.5 & 浮 腫 \\
13 & 28.5 & 型 \\
14 & 74.5 & 軽 症 型 \\
15 & 65.6 & 線 維 型
\end{tabular}

察

25〜 50mg 投与にて 約 $0 \sim 0.15 \mathrm{mcg} / \mathrm{g}$, AKM 20〜 $50 \mathrm{mg}$ 投与にて $0 \sim 5 \mathrm{mcg} / \mathrm{g}$ といずれも， 私共の今回の $\mathrm{CEZ}$ 亿よる成績より低い值を報 告している. 一方，副鼻腔粘膜は，全身投与で は，肉眼的所見で浸潤傾向のものに高い濃度の 移行を認め, 次いで浮腫傾向, 低いのは線維化 傾向のものであり，局所投与では，浮腫傾向の ものに高い值で，次いで浸潤傾向，低いのは線 維化傾向のものであったと報告している．藤谷 ら $^{4)}$ は AB-PG $500 \mathrm{mg}$ 全身投与で上顎洞粘膜 内移行濃度は，1 時間後では測定不能，2 時間 後, $0.41 \mathrm{mcg} / \mathrm{g}, 3$ 時間後 $0.69 \mathrm{mcg} / \mathrm{g}$ と報告し ている，いずれも私共の測定值に比し低い值を 示している. この原因にはいろいろ考元られる が，今回投薬された抗生刜の量は，日常臨床に 使用されている量よりもかなり大量である事， あるいはネブライザーによる投与法による際の 下鼻甲介，鼻茸内の $\mathrm{CEZ}$ 濃度に比較して，洞 内注入した場合の副鼻腔粘膜内濃度が大である 事より，投与法の差によっても粘膜内移行量が 
かなり異なるものと考えられる。一方採取され た組織の楽剤濃度を測定する際, その表面に附 着した抗生剂を滅菌生食水で洗浄するのが一般 に行なわれており，また生食水を数回とりかえ て洗浄している報告 ${ }^{12)}$ みられる。乙の場合の 測定值はかなり低濃度となると考えられる. 採 取された組織を数回に亘り充分洗浄した場合 は，その表面に附着した抗生剤とともに組織内 の抗生剂もある程度流出する可能性もあるの で，私共は生食水洗浄を一回のみにとどめた事 にも，他報告におけるよりも高濃度の值がみら れた原因の一つになるであろう。しかもての場 合は, 組織内抗生剤の流出が防が机ると同時に 組織表面にある抗生㓮が残存する可能性もあ り，ての点も考慮に入れなければならない。

今回の方法で局所に投与された抗生剤が, 鼻, 副鼻腔粘膜内に移行する事が判ったが, 粘 膜内のどの部分にどの様にして浸入するもので あるかを知るには, 抗物質投与後, 粘膜内の組 織学的な移行の検索が必要となる. 図 8 はテト ラサイクリン系薬剤を, 鼻腔内にネブライザー 投与した場合の下鼻甲介粘膜の螢光顕微鏡像で あり，上皮層ならびに鼻腺内に強い螢光がみら れ，乙れらの部位に薬凨が浸入している事が判 る. 更に微細に検索する為には，電子顕微鏡的 検索が有用である為にこの検討を行なった。 図 9 は追跡子として家鬼上顎洞内に注入した
Horseradishperoxidase が線毛細胞間に浸入し ている事を示すものである．乙の微粒子は線毛 細胞内に pinocytosis の形式で吸収されて後, 細胞間隙を主とした通路として，粘膜下層に浸 入する事が判万。なお組織学的な薬物移行の検 索のための試料作成法の詳細および文献的考察 は中井 ${ }^{13)}$ を参照されたい. 今回使用した CEZ は分子量ならびに化学構造式が上記追跡子と異 なるので同等に扱うことはできないが，上の様 な形式で粘膜内に浸入するてとも推定される. しかしての形態的検索は，正常上顎洞粘膜に関 して行なったものであり, 病的粘膜に関しては 異なる所があるととは考光られるが，一つの進 入形式として推測するととができる.

今回の定量的方法による検索では, 肥厚性鼻 炎, 副鼻腔炎においては, 炎症性細胞浸潤の少 ない例が組織内 GEZの量が大であった。一般 飞急性炎症の場合，外部より粘膜内一の物質の 吸収が，正常時に比べ多いといわれる ${ }^{14)}$. 慢性 炎症の場合は，その組織像より推定すると，正 常に近い像を示すほど，その吸収率が大である といえるであろう。他方気道粘膜上皮細胞表面 には，分泌腺よりの分泌液を主体とする粘液層 が存在し，てれが外部より粘膜内への異物の浸 入を妨げる大きな因子となっている。ゆえに粘 淮層を除去する作用をもつ表面活性剤などの併 用は臨床上有用であるといえる。

\section{むすび}

局所投与された抗生剤 CEZ (Cefazolin) の鼻, 副鼻腔粘膜への浸入の状態を生物学的定量法に より検索し, 次の結果を得た。

1. 局所に投与された GEZ は，組織内に移行する.

2. その移行量は，従来報告されている全身投与によるものよりは大である。

3. 肥厚性鼻炎, 慢性副鼻腔炎については, 病理組織学的にみて, 細胞浸潤の少ない例が組織内 濃度が大である。

以上より悬疾患に対して，抗生物質の局所応用がかなり有効である事が証明された。

稿を終るにあたり，御指導御校閲を睗わりました山本馨教授に深謝いたします。

本論文の要旨は第 170 回日耳鼻大阪地方会に扔いて発表した。 


\section{参管文献}

1）佐藤良暢，浅野 登，坂口富美，兵 昇，阿部 鑑儀，鈴木由夫，鶴岡和夫，中村義明，松井隆 夫, 山脇吉次, 吉田二郎：副鼻腔炎に対するネブ ライザー療法の再検討，薬剤組合わせの一例とそ の効果. 耳鼻臨床 $66: 1139 \sim 1151 ， 1972$

2）種村恭夫，藤井尚子：鼻疾患におけるべータメサ ゾン液のネブライザー使用経験について。耳喉 $40: 415 \sim 421 ， 1968$.

3）守安靖廉，奥野恒弥，鎌数清麿，大城 修：抗生 剂の血中及び鼻腔, 副鼻腔粘膜組織内濃度に関す る 2，3 の知見. 耳鼻臨床 $66: 443 \sim 482 ， 1973$.

4）藤谷哲造，志水雄輔，井之口順，岡 睟邦，窯田 洋一郎，雲井健雄，辻 一江，山口昭二 : 慢性副 腔炎上顎洞粘膜上への抗生物質浸透性におよぼす 蛋白分解酵素の影響. 耳鼻臨床 $66: 557 \sim 565$, 1973.

5）三吉康郎，大山 勝，荘司邦夫，山際幹和，森川 謙三 : sulfobenzylpenicillin の慢性副鼻腔炎粘膜 ならびに膜性扁桃炎組織内移行に関する研究.耳 鼻臨床 $67: 889 \sim 894,1974$.

6）五十嵐真：慢性副鼻腔炎における上颓洞粘膜への 抗生物質移行度に 関する研究（筋注の場合）日 日 耳鼻 $81 ： 1440 \sim 1461 ， 1958$.
7）岩沢武彦，木戸 勉: Hetacillin の抗菌力, 血中 濃度, 尿中排泄, 組織内移行ならびそ臨床的応用 亿関する検討。耳喉 $41: 691 \sim 701 ， 1969$.

8）高須照男：慢性副腔炎における楽物療法の基礎的 諸問題. 耳展 $9:$ 補 $4 ； 390 \sim 401 ， 1966$.

9）西端龮一：慢性副腔炎の化学療法. 日本医事新報 No. $1295: 3 \sim 4,1949$.

10）椿 茂和：ネブライザー療法の最近の考元方.耳 展 $11: 285 \sim 287,1968$.

11）坂倉光蔵：慢性副鼻腔炎に対するペニシリン陰圧 煙霧療法の研究. 日耳鼻 $56: 5 ; 330 \sim 359$, 1953.

12）馬場駿吉 : 鼻, 副鼻腔粘膜よりの吸収, 臨床的見 地より. 第11回鼻副鼻腔基礎問題研究会 1974 .

13）中井義明: 鼻, 副鼻腔粘膜よりの吸収. 形態的見 地上り。耳鼻 1975 。印刷中

14）栗田二郎：上頻洞における色素吸収機能について の実験的研究. 耳鼻臨床 $44: 444 \sim 446,1951$.

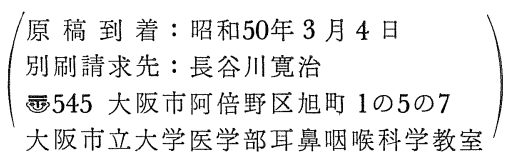

\section{附 図説明}

図 2 鼻茸 細胞浸潤型

図 3 鼻茸 浮腫型

図4 下鼻甲介粘膜 肥大型

図 5 下鼻甲介粘膜 肥厚型

図 6 上䫈洞粘膜 肉芽型

図 7 上颚洞粘膜 軽症型

図 8 テトラサイクリン系薬剤ネブライザー投与後の下鼻甲介粘膜螢光顕微鏡像. 粘膜上皮お よび鼻腺内に強い発色がみられ，上皮下首間質内にも軽度の浸入がみられる。

図 9 上澦洞内 Horseradish peroxidase 注入後の家鬼上類洞粘膜. HRP (矢印)は線毛細胞表 首部とともに pinocytosis によると思われる細胞内浸入及び細胞間隙へ浸入しているのが 認められる。 $(\times 6000)$ 
長谷川・中井論文附図（その1）

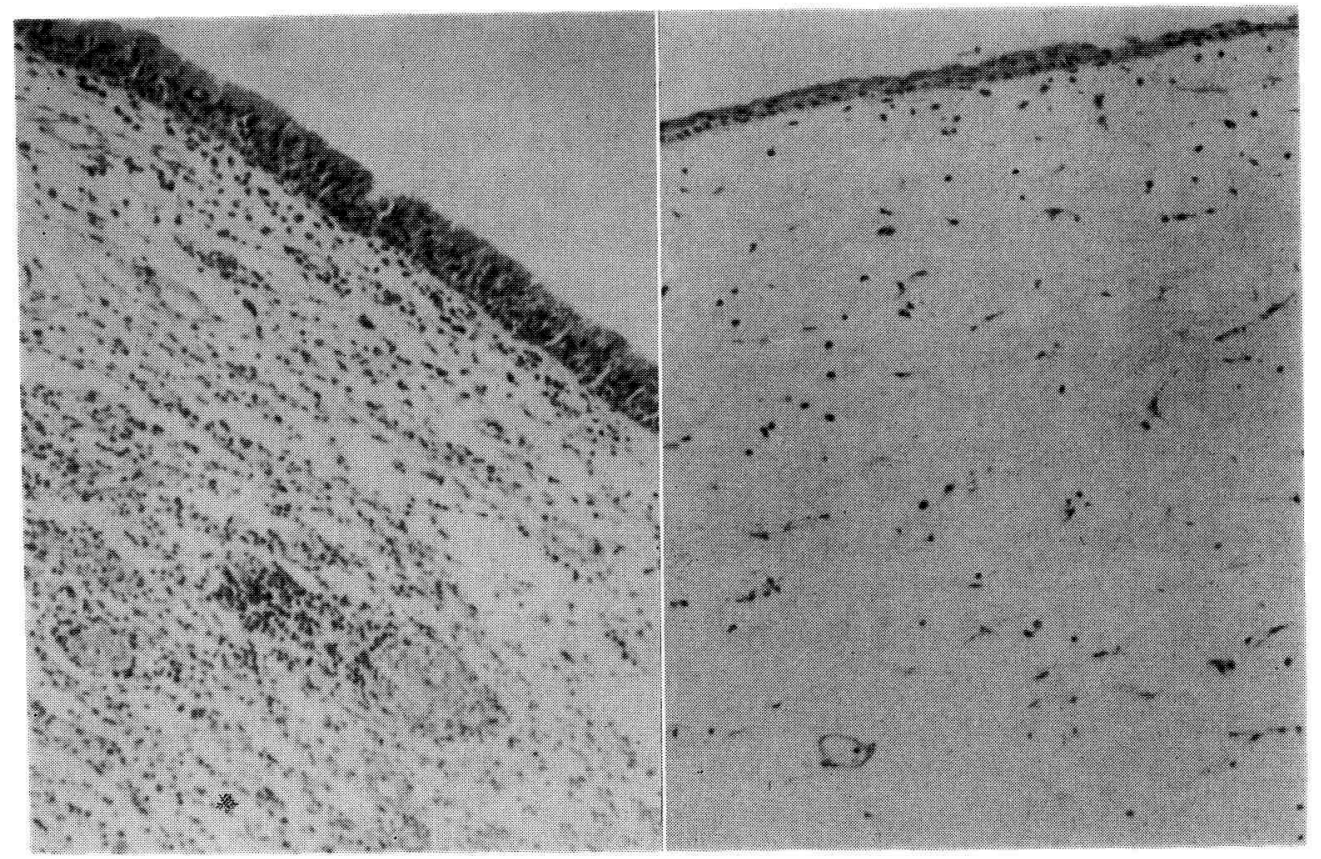

図 2

図 3

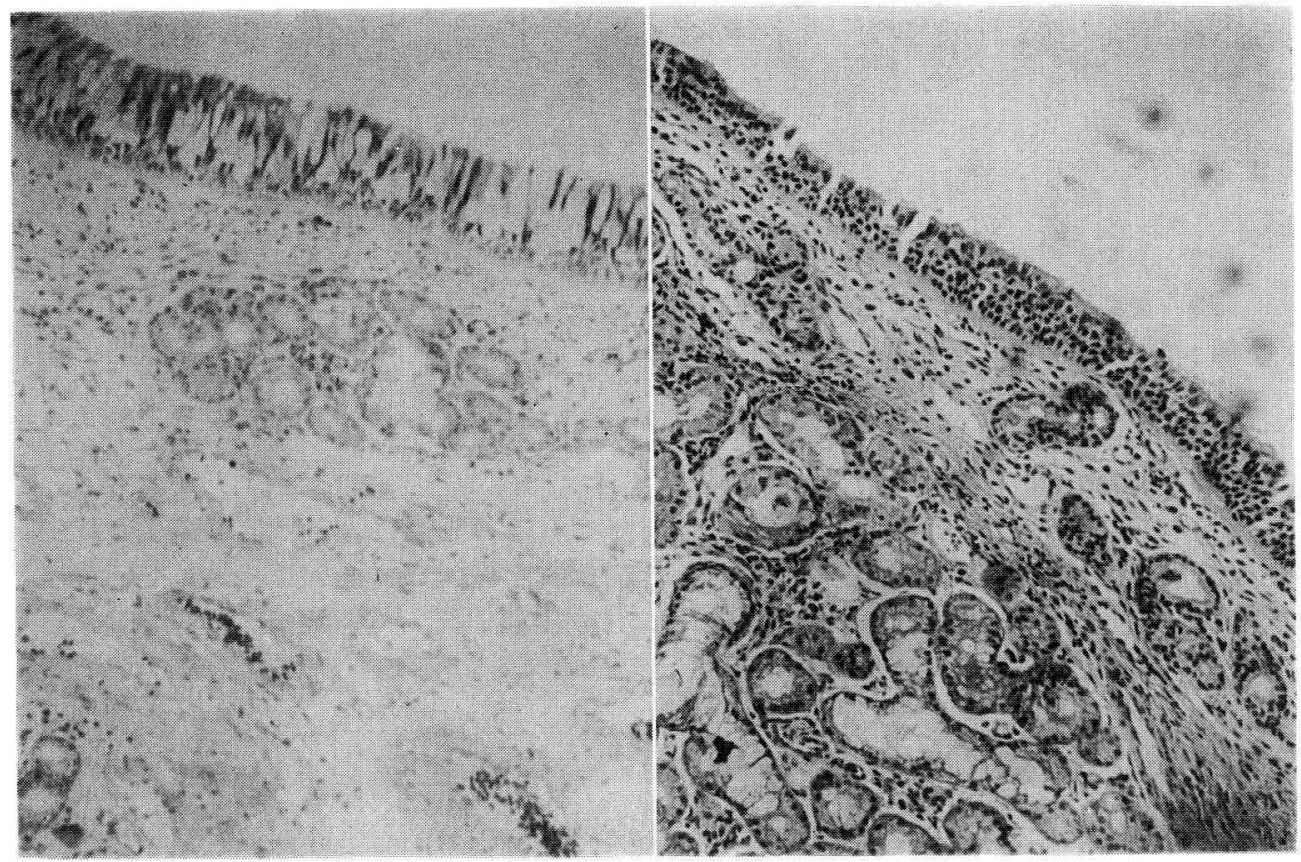

図 4

図 5 


$$
\text { 辰谷川・中井論文附四（その2） }
$$

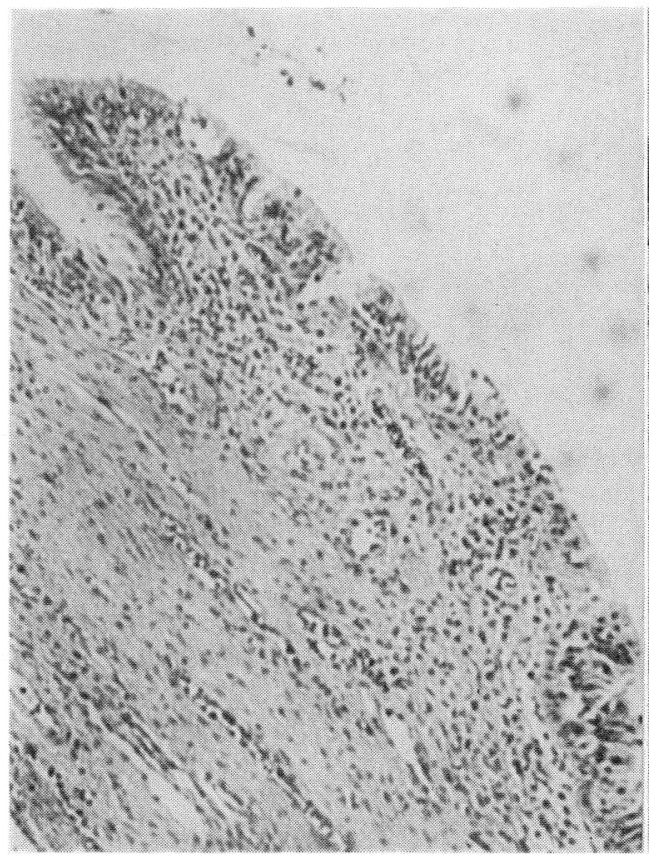

図 6

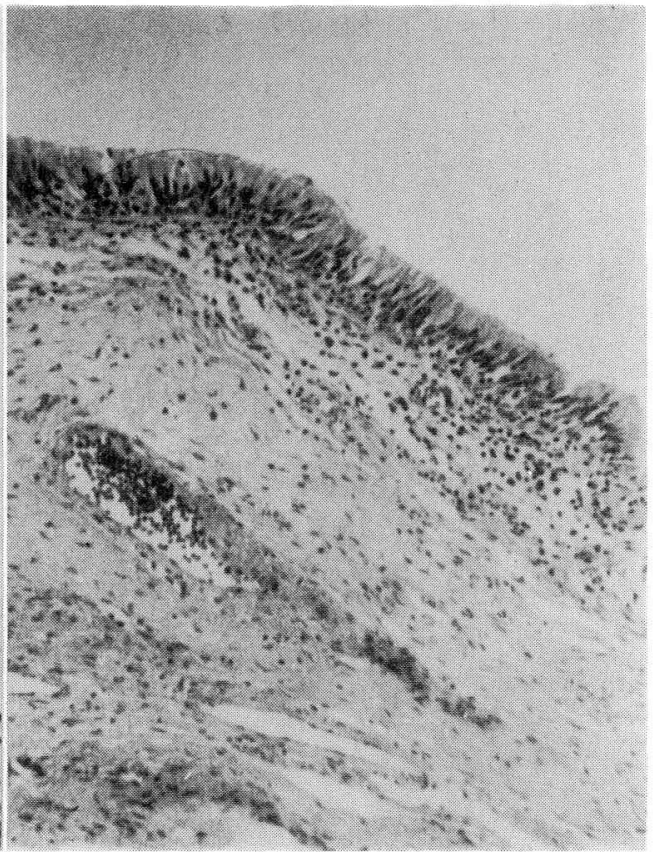

図 7

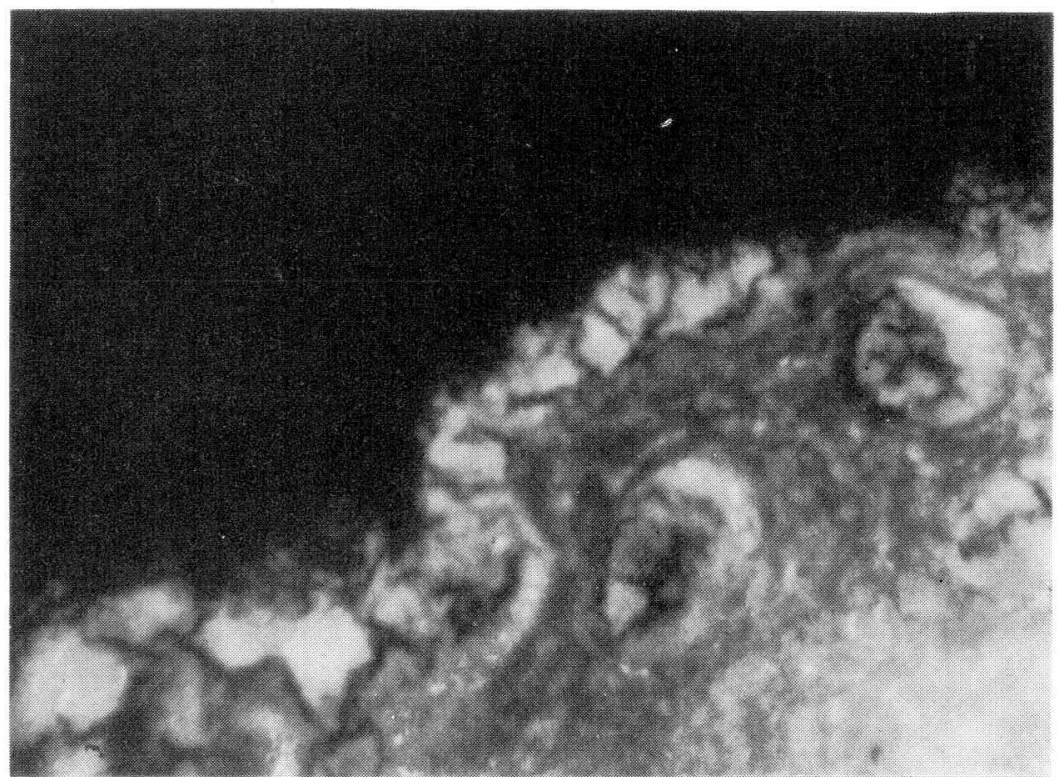

図 8 
長谷川・中井論文附図（その 3 ）

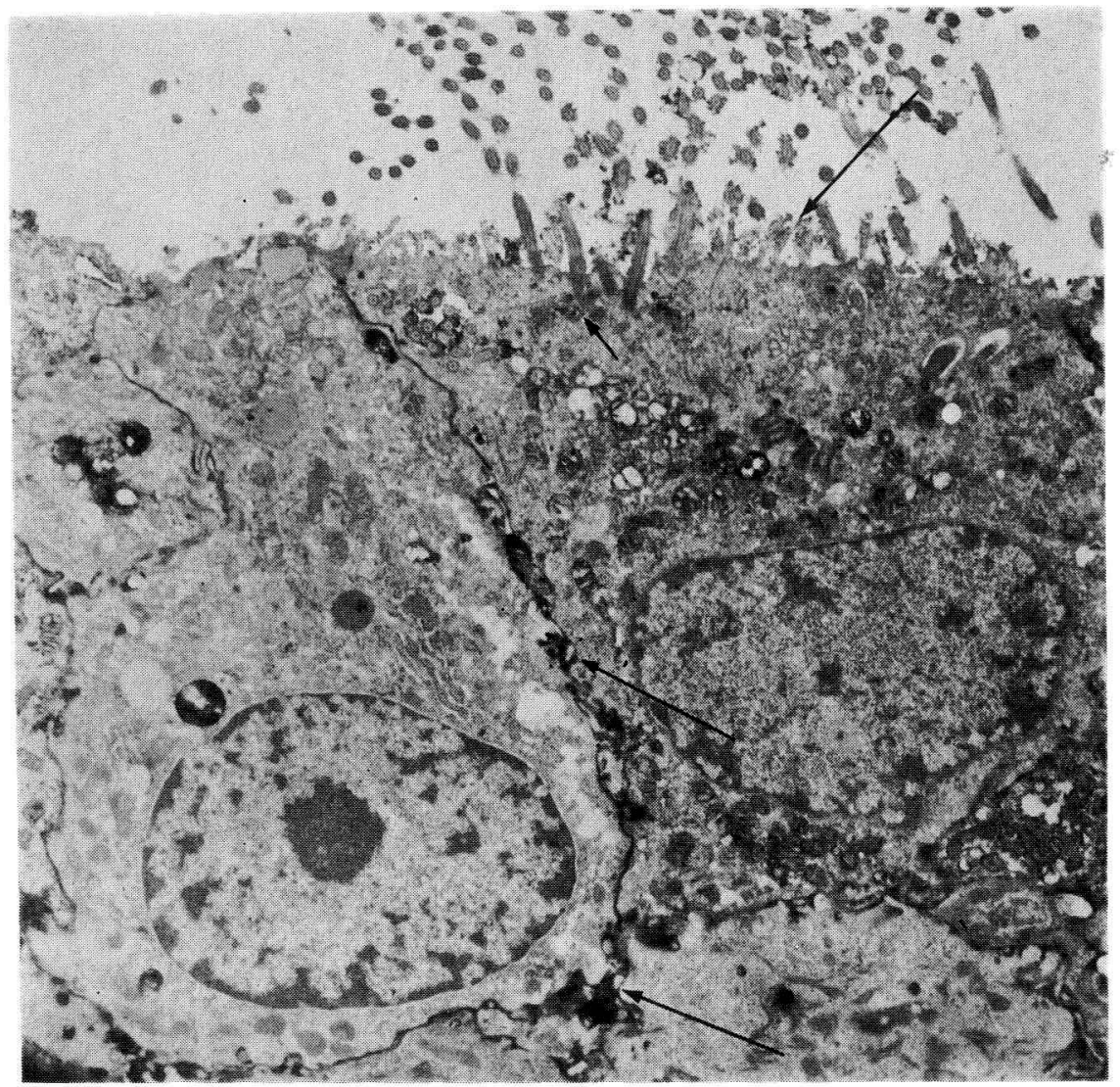

図 9 